\title{
The Struggling English Language Learners: Case Studies of English Language Learning Difficulties in EFL Context
}

\author{
Sultan H. Alharbi ${ }^{1}$ \\ ${ }^{1}$ Department of English Language \& Translation, College of Languages \& Translation, King Saud University, \\ Riyadh, Saudi Arabia \\ Correspondence: Sultan H. Alharbi, Department of English Language \& Translation, College of Languages \& \\ Translation, King Saud University, Riyadh, Saudi Arabia.
}

Received: September 22, 2021

Accepted: October 25, 2021

Online Published: October 28, 2021

doi: $10.5539 /$ elt.v14n11p108

URL: https://doi.org/10.5539/elt.v14n11p108

\begin{abstract}
The term 'struggling language learner' is one that is usually ascribed to students who are trying, without much success to master the English language in an academic setting. As a case study, this study was carried out to gain insights into the 'struggles' of the struggling English as a foreign language (EFL) learners. Ten students were selected from those with the 20th least percentile in their English language courses. Observation of and discussion with these categories of learners revealed that many language learners had a point at which they began to take learning English language more seriously. In such positive or negative situations, their language learning journey improved therefrom. The findings showed that $80 \%$ of the participants believed that their English language proficiency was 'very good', while $20 \%$ of these participants believed that their English language proficiency was 'average'. Also, the findings indicated that there was a statistically significant association (i.e., $p<.05$ ) between English language proficiency of the learners and the following observable attributes: willingness to learn for educational purposes; willingness to learn for career development; and students' continuation without losing focus. The study proposes a fresh evaluation of the problems faced by EFL struggling learners by bringing to light a multifaceted, meaningful consideration of their learning attitudes from socio-psychological point of view, offering a comprehensive account of these learners and their learning difficulties as well as their attitudes and outlook while taking lessons as freshmen at the university.
\end{abstract}

Keywords: EFL university students, difficulties in language learning, the struggling language, reading

\section{Introduction}

For the past ten years, the researcher has worked with the Department of English Language and Translation (DELT) in the College of Languages and Translation (COLT) at King Saud University (KSU) in a variety of capacities. In that time, he has come across students, less than average, who have an especially difficult time learning English language. From his experiences, he has documented issues with a number of these students in order to analyze the problems and set about finding ways to help them adjust. The problems that he has encountered among students include: emotional bursts or learning blocks (Schwab \& Elias, 2014; Reis, 2004). While it would be expected that instructors of English language look directly into the issues students constantly face with grammar, vocabulary, syntax, and so on; more and more studies (e.g., Azar \& Tanggaraju, 2020; Ismail et al., 2014; Pfenninger \& Singleton, 2016) have emphasized the role of motivation in language learning (and in fact, in all learning spheres). Hence, the reason why emotional bursts and learning blocks have been highlighted. Most of these problems stem from teaching and learning mismatch of both the teachers and students. When these problems are left unattended to, students' learning problems become even more complex. The difficulties students encounter in learning have often been found to be influenced by cognition and personalities. The current study addresses the difficulties faced by struggling language learners in an academic setting, i.e., the university. Struggling language learners in this study refers to students who experience problems in the context of reading. In dealing with English language literacy, reading and writing are the last two set of skills that students acquire and are presumably, the most difficult (e.g., Uso-Juan \& Martinez-Flor, 2006; Golkova \& Hubackova, 2014). 
Struggling language learners can be categorized into the following:

1) students who decipher what they have read by investing energy to extract meaning from what sentences/words they have read;

2) students who, despite their poor word-recognition capacity, can understand what is being read to them;

3) students who are capable of decoding sentences, but they do not trigger their schema (mental imagery) and thus do not engage with the text to establish context.

Struggling language learners may have different uses of literacy and different experiences of literacy. Thus, all of these affect the success of students as readers. The traditional approach to teaching reading is to teach the basics through skills-based instructions. Findings of relevant studies (e.g., Gilakjani \& Sabouri, 2016) have suggested that students should improve their basic skills in order for comprehension to fully take place. To understand a text, struggling readers are expected to first decode the meaning of words. Comprehension is however more complex than learning to decode a text. Meanings are derived from sentences from the very beginning. When learners cannot decipher the meaning of words, they are expected to study the context in which it is used and then make an informed guess about its meaning. Alternatively, if it does prove to be a difficult word, they can make use of glossaries or a dictionary. Consequently, a learner learns to recognize a pattern because it is quite possible that such words will occur again in a passage or a reading text. It is important to promote awareness on how literacy fits with life issues such as career goals and personal fulfillment. Thinking and learning processes are shaped by other cultural and national backgrounds. Reading basic sight words is not just as it seems. Students also move on to studying graded word lists, reading oral passages, silent reading and listening comprehension, and discussing activity ideas.

Many struggling language learners have revealed that if they do not read the text aloud, they seem not to be able to make meaning of it (Lane \& Wright, 2011). Being familiar with the text and having gripping thoughts and images about it are also important. An old strategy that remains true when reading is this: (i) think about the questions you envisage a particular text or passage to answer; (ii) write these questions down; (iii) read the text or passage; (iv) add more questions as you read the text or passage for the first time; (v) read the passage a second time with the aim of answering all the questions that you have written down; and lastly (vi) voluntarily, read the passage a third time for clarity purposes. Furthermore, it has been proven that the following strategies can help struggling language learners (Alqarni, 2015):

1) encouraging discussion and collaboration among students - this stimulates English language development.

2) collaborating with teachers of other subject areas. This is important since it is where English language will inevitably be used.

3) research-based strategies for curriculum adaptation. as students advance in their courses of study, they are inevitably exposed to different vocabularies. their English language instructors can help by ensuring that they are familiar with many of these vocabularies before they get to use them in subject classes.

4) at each point in time, teachers should be willing to meet and exceed the expectations of struggling language learners.

5) policies are an important part of the process. sound, research-based educational policies are necessary for the greater support of teachers.

6) lastly, teachers are expected to always listen to the needs of students and maintain open relationships in which students are able to state their problems freely.

To analyze language learning difficulties among a set of students with early intermediate level of their university education, the current study adopted the case study methodology employed by Hidayati (2021). It was preferred because it depended on observations and cases in their natural environment to provide exact and integrated results keeping in view the main purpose of resolving the problems of language learners. The remainder of this article is divided into the following parts. Section (2) is a review of some relevant studies. Section (3) provides information data collection and analysis. Section (4) presents the main findings and their discussion. Section (5) gives an overview of the current study and describes the implications of its findings.

\section{Literature Review}

The current article proposes a fresh evaluation of the problems faced by struggling language learners by bringing to light a multifaceted, meaningful consideration of their learning attitudes from socio-psychological point of view. The researcher has offered a comprehensive account of these learners and their learning difficulties as well as their attitudes and outlook while taking lessons as freshmen at the college. The results suggested that teaching 
methodologies and the lack of motivation and emotional bursts contributed to their difficulties to a great extent. In his findings, $\mathrm{Li}$ (2004) also suggests that the teachers' inability to understand the reason behind the low performance of the learners, their lack of communication with them, and the learners' lack of interest have a negative impact on the learners' proper language acquisition. It is inevitable in this context to connect the instructional material with the cultural background of the learners, identify and work on their requirements so as to build a result-oriented language teaching and learning atmosphere.

Almusharraf (2020) offers a qualitative case study where language teachers were given a relatively longer period of time to observe and assess their teaching methodologies and the nature of their active participation in the language development of their learners in order to arrive at an understanding of their learning drawbacks. The study makes use of the relationship between social interaction and language use. The learners were allowed to inspect their own beliefs and assumptions, so as to be self-directed, reasonable, collaborative, and considerate in their socio-cultural atmosphere of language learning. Almusharraf (2020) found that the independence given to the learners allowed them to realize their weaknesses and inspired them to reshape their learning attitudes and develop their vocabulary knowledge in a significant way. It is quite inevitable, therefore, that struggling language learners are given enough time and space to reflect on their learning difficulties and possess a sort of autonomy to find their own solutions to them. This kind of collaborative and of self-directed language learning provides learners with a substantial impetus and motivation to involve themselves in the language classrooms. Stressing on the importance of collaboration and teacher-student interaction in language learning contexts, Gan (2021), in his research on the language problems faced by the Chinese students, observes that it is inevitable for teachers to understand the learners' expectations, beliefs, personality, and knowledge, and the learners to realize the reasons behind their weaknesses. This would motivate the learners and equip the teachers with the knowledge without which language teaching can never be successful. Active teacher-student engagement and collaboration goes a long way in helping students build up on their language skills (Hiver, et al., 2021; Fei \& Derakhshan, 2021; Oppermann \& Lazarides, 2021). This professional and helpful relationship can assist English as a foreign language (EFL) instructors in their teaching process and motivate students to learn in an atmosphere which is taken out of their textbooks and deals with their everyday life and experiences. A non-interactive language class and the teachers' failure in trying to understand the behaviors, preferences, and perspectives of their students shall always result in a botched language teaching practice (Mystkowska-Wiertelak, 2020). Therefore, in the language teaching and learning situation, teachers' experiences and teaching methodologies alone cannot guarantee students' successful language acquisition. It is inevitable to identify the learners' personality traits and apply methods to motivate them to create a holistic atmosphere to help students transform themselves and learn.

Reflecting on the problems faced by struggling Saudi EFL learners, Drbseh (2019) observes that one of the main problems lies with teaching language through methodologies which are unnecessary and obsolete and classroom teaching is not student-centered. He lays stress on developing an appropriate student aptitude and initiative to motivate students to prepare themselves for collaborative language learning. Drbseh (2019) advocates for a holistic and interactive teaching-learning approach away from the archaic rote learning tradition. Furthermore, Drbseh (2019) claims there is a severe lack of proposals or plans to expose English to students at the very beginning of their learning stages. Khan (2011) stresses that there is a need to take careful planning, and to recognize the requirements of learners and their objectives. Apart from what the researchers noted here feel about the impediments that stall language learners in their struggle to learn a foreign language, lack of motivation is a glaring hurdle. Motivation plays a crucial function in language learning atmosphere. It has to be constant, and the responsibility lies on teachers to see that learners are not left unmotivated. Struggling language learners must be exposed to their second languages as they had been to their first language (Ismail et al., 2014). Kormos (2020) rightly argues that there is an urgent need to investigate and analyze the difficulties that second language learners in the twenty-first century are facing in language acquisition. He holds forth that though the consequences of second language learning have been methodically and comprehensively researched till date, there are still grey areas where there is a need to re-evaluate the needs of language learners and the language teaching pedagogy. There are still some specific learning difficulties which have to be understood and initiate an all-encompassing language learning context by inaugurating a useful language learning program in real situations (Al-Nasser, 2015). It has been observed by various researchers (e.g., Al-Nasser, 2015; Azar \& Tanggaraju, 2020; Norwich, 2014; Kormos, 2020) that learning difficulties are hypothesized differently in different educational and academic atmospheres. English language learning obstacles can be personal; they can be common and similar, but their solution lies in recognizing the strengths and weaknesses of the language learners, and their attitudes to second language acquisition. 
It is imperative, therefore, to employ those tools and methodologies that suit the needs and desires of English language learners so that their struggle becomes useful and results in positive outcomes. The difficulties in English language learning have also to do with cognitive individual differences (e.g., Pfenninger \& Singleton, 2016), and, therefore, the current study focused on the individual English language learners, their learning difficulties and needs as well as their reflections about their weaknesses. The study has also tried to assess student willingness and the effectiveness of the instructional programs for teaching English language to arrive at a tangible diagnosis and useful suggestions for better implementation and further research studies in the area.

\section{Methodology and Procedures}

To achieve the aim of this study, the following methodologies were put in place:

\subsection{Study Participants and Sample Selection}

There are numerous students studying English language all over the world; however, only a fraction of that population can be selected to fulfill the objectives of this study. In many countries where English language is being studied as EFL, different researchers have dealt with the problem of the struggling language learner in diverse ways. With the researcher currently teaching at a national university in Saudi Arabia, this study aimed to study the problems of a selected few who have difficulties learning the English language and applying it in their courses of study. Selecting students from KSU gives the researcher an influence on the students under his care. Moreover, the researcher chose students from the third year of study because selecting students from different years of study at the university would mean that those students have different levels of exposure to English language. While in a single class setting, students could still have different levels of exposure to English language, the difference in level of exposure would be relatively minimal (compared to students from different class settings and contrasting years of exposure to the language).

The researcher chose a total of ten case studies for a qualitative analysis of the difficulties in English language learning. These few numbers of case studies mean that the researcher was able to analyze each case study in detail and reveal reasonable assumptions about each one. The selection of a larger number of case studies might mean that the researcher has to deal with more cumbersome data $(\mathrm{Cln}, 2013)$. The study sample consisted of ten students in their third year of study in the College of Engineering of KSU, Riyadh, Saudi Arabia. The students are enrolled in English language courses as a part of their bachelor's degree requirements, and these language courses are offered by the Department of English Language and Translation (DELT) in the College of Languages and Translation (COLT) at King Saud University (KSU). A first-year engineering student mostly only gets exposed to English as a General Language. This could translate to only a level above secondary-level English language. Having studied English language for two years or more in the university, a student is considered proficient enough to participate in this study. Since this study addresses the problems of struggling language learners, the researcher chose to use students who fall into the bottom 20th percentile of their English language courses (Guarino, et al., 2015). Thus, ten students were randomly selected. While the researcher could simply have chosen the ten least performing students in the classroom, this might have made for a biased study as the same set of ten students may not continually be the least set of students each semester. All students were Arabic native speakers. The students were assured that their responses would remain confidential and would be used for research purposes only.

\subsection{Data Collection and Analysis}

The current study made use of structured interviews as a qualitative data gathering tool. This is considered to be more comprehensive compared to a questionnaire method of data collection. While a questionnaire will acquire some of the useful information required for the purpose of this study, interviews hold more value for achieving the objectives of case studies (Seale, 2012). As the study is exploratory so rather than employing efforts to prove a hypothesis, it aims to explore the problem a qualitative interview-based study would make more sense where possible answers are not defined. Moreover, based on the responses obtained through the structured interviews, each respondent was rated on a scale of 1 to 5 based on the following attributes (Bentler, 2007).

- willingness to learn for educational purposes

- willingness to learn for career development

- willingness to improve their English language proficiency for general purposes.

- willingness to master the English language in a relatively short time.

- continuation of students' learning without losing focus. 
In order to assess whether these attributes had any role to play in the English language proficiency of the students, Chi square test samples was carried out using the SPSS software (version 23).

\section{Results and Discussion}

\subsection{Participants' Responses}

Following the confirmation and detailing of the problem, the responses were checked for: attitude of the students towards English learning, their purpose for studying English, their description of certain events on their journey towards literacy; and ultimately, exploration of these patterns in the responses of other respondents to detail possible useful conclusions. As can be seen in Table 1, each two of the ten respondents were grouped together in on category based on similarity of responses in order to further simplify the conclusions drawn. Pseudonyms were assigned to them to maintain anonymity.

Table 1. Grouping of respondents

\begin{tabular}{lll}
\hline Category & Respondent & Pseudonyms \\
\hline $1^{\text {st }}$ Category & Respondent 1 & Adel-1 \\
& Respondent 2 & Adel-2 \\
$2^{\text {nd }}$ Category & Respondent 3 & Khalid-1 \\
& Respondent 4 & Khalid-2 \\
$3^{\text {rd }}$ Category & Respondent 5 & Sami-1 \\
& Respondent 6 & Sami-2 \\
$4^{\text {th }}$ Category & Respondent 7 & Muhammad-1 \\
$5^{\text {th }}$ Category & Respondent 8 & Muhammad-2 \\
& Respondent 9 & Othman-1 \\
& Respondent 10 & Othman-2
\end{tabular}

Respondents given the same pseudonym, differentiated by 1 or 2 responded similarly to certain questions. Hence, they were grouped together into category.

\subsubsection{Responses of $1^{\text {st }}$ Category of Respondents}

According to Adel-1 and Adel-2, they were sufficiently proficient in English language, choosing 4 on a scale of 1 - 5, 1 meaning Poor and 5 meaning Excellent. Struggling language learners usually believe that they are proficient enough (but not in the academic sphere). This perception is borne out of their journey to studying English language prior to arriving at the position they currently are. Answering the question on who or what has influenced their desire to learn the English language, the respondents answered with education and developing their career, respectively. These are usually the main driving force for learning English language in any setting (Adjoe, 2017). Learners either need to further their education or advance their career. Rarely is it desired or mandated for entertainment purpose. On occasions where it brings benefits for entertainment purposes, it is usually learned passively. In this case, it is what is called 'serious leisure' (Freed, et al., 2003). Describing certain events that have occurred in their language learning journey, Adel-1 told of an incident where his 'backpack' was stolen. In this setting, he was relatively new to learning English language in the USA (America). Unfortunately, he also only had friends who came from the countries of Japan and China and were also new learners of English language like himself. This created a barrier in getting the help that he required. As a reinforcement, this improved his determination to put more effort into learning the English language, which according to the respondent, has paid off positively. Several students also highlight instances after which their English language learning journey took a turn for the better (Floris and Renandya, 2020).

\subsubsection{Responses of $2^{\text {nd }}$ Category of Respondents}

Khalid-1 and Khalid-2 both noted that being in a country where only English language is spoken (where their mother's tongue was not spoken) considerably helps to learn the English language better. This is the case since one would barely have an option other than to speak in English. While this might be useful for communication purposes, Khalid-1 and Khalid-2 still mentioned that they face problems adjusting to English language in the academic setting. They specifically mentioned that they found academic writing to be challenging. On what techniques respondents use to make studying English language easier, Khalid-1 and Khalid-2 both mentioned that they love to read avidly. These include texts that are at their level and are related to their field. This was also 
similar to the responses of Adel-1 and Adel-2 who mentioned that they actually make it a habit to read every time they had an English language lesson in school. This helps their retentive memory (Ghorbani \& Riabi, 2011).

\subsubsection{Responses of $3^{\text {rd }}$ Category of Respondents}

Sami-2 mentioned the importance of integrating technology into English language classrooms (Asmali, 2018). In his case, he cited Mr. Duncan on YouTube. Mr Duncan has a channel on YouTube where he helps students and learners of English language to learn conversational English. In Sami-2's opinion, this has brought numerous benefits to him. Sami-1 mentioned that he enjoyed watching movies in English language whether subtitled or not as they help improve his English communication (speaking and listening skills). This was similar to the response of Khalid-1 and Khalid-2 above who mentioned that travelling to a foreign country forces them to speak the language and develop proficiency. Of all responses given, personal experiences particularly drew insights for this research. Asked what anecdote particularly influenced his journey to learn English language or to improve in his pursuit, Sami-2 mentioned a moment he needed to represent his school for a particular debate. He mentioned that "it had both pros and cons" on his language learning sojourn. He said that when he was asked to step forward, he started discovering his abilities, as it happens with most language learners. Every language learner at a moment in his journey into language learning has two choices: he can either draw back and surrender, or he can step forward to growth. Sami-2 said he opted for the second. While most of the respondents mentioned factors relating to motivation (that is, being soft and patient), Sami-1 introduced the phrase of KISS - that is, teachers should always keep notes and lessons short and simple (Keep It Short and Simple).

\subsubsection{Responses of $4^{\text {th }}$ Category of Respondents}

About the advice they would give to teachers of English language, Muhammad-1 and Muhammad-2 mentioned that they would particularly like teachers to be soft on students in order to motivate them. They believed that it takes time to learn English language. English language is a relatively difficult language to master (NSA, 1975). Like many other language learners, Muhammad-1 and Muhammad-2 believed that one could sometimes find oneself in a rather intimidating situations where one becomes self-conscious to communicate in English language. On what their most desirable wish is in language learning, Muhammad-1 and Muhammad-2 both mentioned that they would particularly like to understand what the best techniques for learning the language in a short time are.

\subsubsection{Responses of $5^{\text {th }}$ Category of Respondents}

The responses of these set of learners are rather on a personal level. Describing who or what has influenced their journey towards English language learning, they both responded that the author has a had a positive impact on their journey towards learning the English language. Othman-1 stated that his teacher's teaching style particularly influenced him. On what he would advise administrators, Othman-2 pointed out that most teachers teach only to instruct, rather, he wished that English language classes could be more challenging while being fun. Mentioning the use of technology, they would both like class session to include the use of technology, like smart devices and translation apps.

4.2 Role of Respondents' Motivations for Learning English and Continued Focus on Learning on Their English Language Proficiency

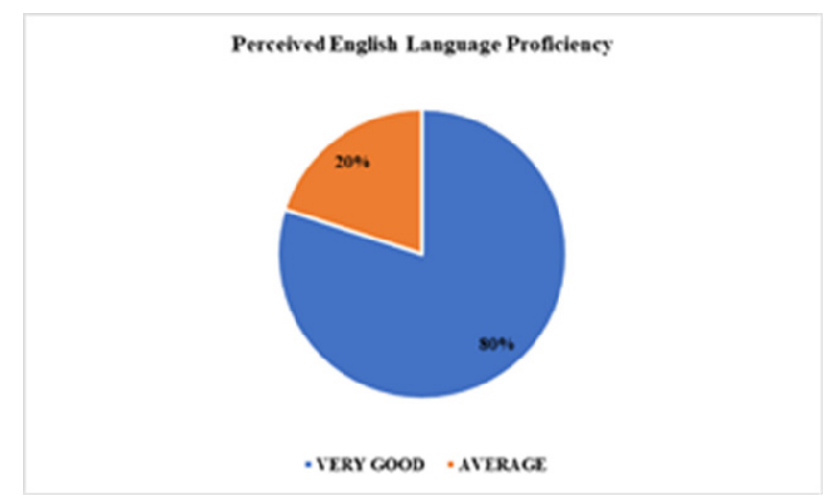

Figure 1. Perceived English Language Proficiency among Students

Of the responses collected, the one most appropriate for a quantitative representation is the percentage of respondents who believed they were proficient. The pie chart in Figure 1 above represents the percentages of respondents accordingly. As shown in Figure. 1, 80\% of the respondents believed that they were proficient "very 
good" in English language. Only 20\% believed that their proficiency in English language was average "3" (Figure 1). As is mentioned earlier in this article, it needs to stress here that language learners who make a great effort in acquiring English as EFL normally tend to consider themselves quite competent colloquially than academically. Their belief is based on their educational visits abroad before joining classes at the university.

To assess the role of the learners' motivations for learning English and continued focus (Bentler, 2007) on their English language proficiency, Chi Square Test was carried out, the results for which are presented in Table 2. The results show that willingness to learn for educational purposes, willingness to learn for career development and continued learning without loss of focus are statistically significantly associated with the English language proficiency of the students, whereas the willingness to improve English for general purposes and willingness to master English in a relatively short time are not statistically significantly associated with the learners' English language proficiency.

Table 2. Results of Chi Square test of selected attributes against English language proficiency of respondents

\begin{tabular}{llll}
\hline & Pearson Chi-square & $p$-value & Likelihood ratio \\
\hline Willingness to learn for educational purposes & 10 & 0.04 & 10.01 \\
Willingness to learn for career development & 10 & 0.04 & 10.01 \\
Willingness to improve English for general purposes & 3.75 & 0.15 & 4.46 \\
Willingness to master English in a relatively short time & 5.83 & 0.12 & 6.19 \\
Continued learning without loss of focus & 10 & 0.02 & 10.01 \\
\hline
\end{tabular}

In all, certain pattern was found in the responses of participants. Based on observation, all the respondents showed a positive attitude towards learning English language, inside and outside the academic setting. They all would continually like to improve all of their English language skills, i.e., listening, speaking, reading and writing. Their purpose for studying English language was mainly for education and/or advancement of their career. This could be because the participants were all chosen from an academic setting according to the purpose of this study. None answered that they required it for entertainment purposes like tour of other countries or tour of English-speaking countries. Furthermore, the case study also provides the varied view of students as they serve as an important asset for continually improving the methods of teaching English language. Examining case studies like these shifts the focus from a discipline-bound curriculum to a broad interdisciplinary one and student-centered one. Struggling language learners usually quote: "stumbling through too many distractions", many find language learning to be too boring and difficult (Cohen, 2007). On the other hand, the caring attitude of teachers has a positive impact on students. Notably, those who are termed 'struggling language learners' most likely use English language successfully outside the classroom (e.g., Rubinstein-Avila, 2003; Cohen, 2007). The term 'struggling language learner' basically refers to the context of academic literacy.

The goal of reading a text is to make meaning from it, and in most cases, write a summary or provide a critique. For many students, the section where students develop problems in English language development is: reading (Ivey, 1999). Ivey's (1999) definition of a successful reader is one who has learned to read, and in addition, summarize what they have read and possibly critique it. By the third year, most learners should be able to use English language in connection to how it is related to their field of study successfully. The possibility of English language proficiency among students differs according to their interests, motivation, gender, age, personalities, previous exposure to English language and even proficiency in their first language (mothers' tongue) (e.g., Segalowitz \& Frenkiel-Fishman, 2005; Svanes, 1987; Inbal et al., 2017). It is expected that students should have had previous exposure to English language to such an extent that they can take beginning university courses (Rubinstein-Avila, 2003). The flexibility of a teacher eases participation and ensures students' engagement in a variety of literary practices. Having periods dedicated to practice reading, being provided with access and exposure, and a variety of reading texts to choose from is a key ingredient. Students look forward to an anxiety-free classroom. Reading collectively with colleagues and making use of learning strategies boost students' confidence in settings outside the classroom. Generally, students expect the classroom to be fun and factual. They are even more excited when texts used in the classroom are closely related to what is available in the professional world.

\section{Conclusion}

The current study has attempted to present through various case studies some of the challenges and difficulties that EFL learners face in learning English language. The generalizability of the findings obtained in this study is subject to certain limitations. For instance, one obvious limitation of the study is the lack of female students. If 
female students had participated, the results might be different. Another limitation of the study is the limited sample size (i.e., ten case studies), and therefore, this study should be replicated with a larger number of students. Further, it would be interesting to compare results across levels of proficiency as well as gender. Despite these limitations, the findings of the present study have yet numerous pedagogical implications. That is, the findings can be helpful in redefining the EFL learning course materials and implementing some of the suggestions placed. English language instructors, for instance, should try to create empathetic, socially responsive learning environment, and the teaching process should focus on and help develop the learners' oral language improvement and vocabulary acquisition. Additionally, proper attention needs to be given to evolve reading comprehension strategies particularly activating and using the learners' background knowledge and teach them thinking strategies to draw inferences. Humanizing struggling language learners through interviews with them creates more empathy towards their case and the need to seek a solution. Struggling EFL learners deserve a great deal of credit for their perseverance and their ingenuity in dealing with the challenges they encounter. In general, they show the willingness to learn, improve and master the language in a relatively short period. They should feel cared for and respected while also being provided with the academic and professional tools they will need to move forward. Acquiring literacy strategies gives struggling EFL learners' greater confidence and authority about their language development. English language is complex and requires the mastery of complex contexts. However, with hard work and dedication, more students who work hard to be successful can escape the label of 'the struggling language learner'. It is hoped that this portrait of language learners who struggle to develop English language literacy will help EFL instructors alike, providing fresh perspectives on how to deal with and help struggling language learners.

\section{Acknowledgments}

The author expresses his appreciation to the Deanship of Scientific Research at King Saud University, Saudi Arabia, and the Research Center at the College of Languages \& Translation for offering support for the current article.

\section{References}

Adjoe, C. (2017). English studies and future career opportunities: How English students construct themselves in a Ghanian university department. Journal of Humanities and Social Sciences, 22, 1-8. https://doi.org/10.9790/0837-2205030108

Almusharraf, N. (2020). Teachers' perspectives on promoting learner autonomy for vocabulary development: A case study. Cogent Education, 7, 1-23. https://doi.org/10.1080/2331186X.2020.1823154

Al-Nasser, A. S. (2015). Problems of English language acquisition in Saudi Arabia: An exploratory-cum-remedial study. Theory and Practice in Language Studies, 5, 1612-1619. https://doi.org/10.17507/tpls.0508.10

Alqarni, F. (2015). Collaborative strategic reading to enhance learners' reading comprehension in English as a foreign language. Academic Journal of Interdisciplinary Studies, 4, 161-167. https://doi.org/10.5901/mjss.2015.v4n1p161

Asmali, M. (2018). Integrating technology into ESP classes: Use of student response system in English for specific purposes instruction. Teaching English with Technology, 18, 86-104.

Azar, A. S., \& Tanggaraju, D. (2020). Motivation in second language acquisition among learners in Malaysia. Studies in English Language and Education, 7, 323-333. https://doi.org/10.24815/siele.v7i2.16506

Bentler, P. M. (2007). On tests and indices for evaluating structural models. Personality and Individual Differences, 42, 825-829. https://doi.org/10.1016/j.paid.2006.09.024

Cln, L. I. S. (2013). Data collection techniques a guide for researchers in humanities and education. International Research Journal of Computer Science and Information Systems, 2, 40-44.

Cohen, J. (2007). A case study of a high school English-language learner and his reading. Journal of Adolescent \& Adult Literacy, 51, 164-175. https://doi.org/10.1598/JAAL.51.2.7

Drbseh, M. M. H. (2019). Saudi EFL learners' difficulties in learning English: A case of secondary school students. Journal of Applied Linguistics and Language Research, 6, 140-151.

Fei, X., \& Derakhshan, A. (2021). A conceptual review of positive teacher interpersonal communication behaviors in the instructional context. Frontiers in psychology, 12, 2623. https://doi.org/10.3389/fpsyg.2021.708490 
Floris, F. D., \& Renandya, W. (2020). Inspirational Stories from English Language Classrooms. Malang, East Java: Indonesia.

Freed, B., So, S., \& Lazar, N. A. (2003). Language learning abroad: How do gains in written fluency compare with gains in oral fluency in French as a second language? ADFL bulletin, 34, 34-40. https://doi.org/10.1632/adfl.34.3.34

Gan, S. (2021). The role of teacher-student relatedness and teachers' engagement on students' engagement in EFL classrooms. Frontiers in psychology, 12, 1-4. https://doi.org/10.3389/fpsyg.2021.745435

Ghorbani, M. R., \& Riabi, N. K. (2011). The Impact of memory strategy instruction on learners' EFL vocabulary retention. Theory and Practice in Language Studies, 1, 1222-1226. https://doi.org/10.4304/tpls.1.9.1222-1226

Gilakjani, A. P., \& Sabouri, N. B. (2016). How can students improve their reading comprehension skills? Journal of Studies in Education, 6, 229-240. https://doi.org/10.5296/jse.v6i2.9201

Golkova, D., \& Hubackova, S. (2014). Productive skills in second language learning. Procedia-Social and Behavioral Sciences, 143, 477-481. https://doi.org/10.1016/j.sbspro.2014.07.520

Guarino, C., Reckase, M., Stacy, B., \& Wooldridge, J. (2015). A Comparison of student growth percentile and value-added models of teacher performance. Statistics and Public Policy, 2, 1-11. https://doi.org/10.1080/2330443X.2015.1034820

Hidayati, L. (2021). Case-based method and its implementation in English for medical purposes. Journal of Language, Literature, and English Teaching, 2, 1-7. https://doi.org/10.31629/juliet.v2i2.3695

Hiver, P., Al-Hoorie, A. H., Vitta, J. P., \& Wu, J. (2021). Engagement in language learning: A systematic review of 20 years of research methods and definitions. Language Teaching Research, 1, 1-30. https://doi.org/10.1177/13621688211001289

Inbal, I., Vingron, N., Baum, S. R., \& Titone, D. (2017). Bilingualism in the real world: How proficiency, emotion, and personality in a second language impact communication in clinical and legal settings. Translational Issues in Psychological Science, 3, 48-65. https://doi.org/10.1037/tps0000103

Ismail, S. A., Abdullah, H., \& Ghani, M. F. (2014). Attitudes and motivation toward learning the English language among students from Islamic education system background: Exploring the views of teachers. Journal of Education and Learning, 8, 195-208. https://doi.org/10.11591/edulearn.v8i3.262

Ivey, G. (1999). A multicase study in the middle school: Complexities among young adolescent readers. Reading Research Quarterly, 34, 172-192. https://doi.org/10.1598/RRQ.34.2.3

Khan, I. A. (2011). Learning difficulties in English: Diagnosis and pedagogy in Saudi Arabia. Educational Research, 2, 1248-1257.

Kormos, J. (2020). Specific learning difficulties in second language learning and teaching. Language Teaching, 53, 129-143. https://doi.org/10.1017/S0261444819000442

Lane, H. B., \& Wright, T. L. (2011). Maximizing the effectiveness of reading aloud. The Reading Teacher, 60, 668-675. https://doi.org/10.1598/RT.60.7.7

Li, G. (2004). Perspectives on struggling English language learners: Case studies of two Chinese-Canadian children. Journal of Literacy Research, 36(1), 31-72. https://doi.org/10.1207/s15548430jlr3601_3

Mystkowska-Wiertelak, A. (2020). Teachers' accounts of learners' engagement and disaffection in the language classroom. The Language Learning Journal, 1, 1-13. https://doi.org/10.1080/09571736.2020.1800067

Norwich, B. (2014). Recognising value tensions that underlie problems in inclusive education. Cambridge Journal of Education, 44, 1-16. https://doi.org/10.1080/0305764X.2014.963027

NSA. (1975). Foreign Language Learning: A comparative analysis of relative difficulty. Retrieved from https://www.nsa.gov/Portals/70/documents/news-features/declassified-documents/cryptologic/foreign_lang uage.pdf

Oppermann, E., \& Lazarides, R. (2021). Elementary school teachers' self-efficacy, student-perceived support and students' mathematics interest. Teaching and Teacher Education, 103, 103351. https://doi.org/10.1016/j.tate.2021.103351

Pfenninger, E. S., \& Singleton, D. (2016). Affect trumps Age: A person-in-context relational view of age and motivation in SLA. Second Language Research, 32, 311-345. https://doi.org/10.1177/0267658315624476 
Reis, L. P. (2004). Investing the effect of language learning strategies teachings on the learning process of EFL students with language learning difficulties (Unpublished master dissertation). Federal University of Santa Catarina, Florianopolis, Brazil.

Rubinstein-Ávila, E. (2003). Conversing with Miguel: An adolescent English language learner struggling with later literacy development. Journal of Adolescent \& Adult Literacy, 47(4), 290-301. Retrieved from https://www.jstor.org/stable/40014775

Schwab, Y., \& Elias, M. J. (2014). From compliance to responsibility: Social-emotional learning and classroom management. In C. M. Evertson \& C. S. Weinstein (Eds.), Handbook of classroom management: Research, practice, and contemporary issues (pp. 309-341). NJ: Lawrence Erlbaum Associates.

Seale, C. (2012). Researching Society and Culture. New York: Sage Publications Ltd.

Segalowitz, N., \& Frenkiel-Fishman, S. (2005). Attention control and ability level in a complex cognitive skill: Attention shifting and second-language proficiency. Memory \& Cognition, 33, 644-653. https://doi.org/10.3758/BF03195331

Svanes, B. (1987). Motivation and cultural distance in second language acquisition. Language Learning, 37, 341-359. https://doi.org/10.1111/j.1467-1770.1987.tb00575.x

Uso-Juan, E., \& Martinez-Flor, A. (2006). Approaches to language learning and teaching: Toward acquiring communicative competence through the four skills. In E. Uso-Juan \& A. Martinez-Flor (Eds.), Current trends in the development and teaching of the four language skills (pp. 3-28). Berlin, Germany: Mouton de Gruyter. https://doi.org/10.1515/9783110197778.1.3

\section{Copyrights}

Copyright for this article is retained by the author(s), with first publication rights granted to the journal.

This is an open-access article distributed under the terms and conditions of the Creative Commons Attribution license (http://creativecommons.org/licenses/by/4.0/). 